DOI: $10.15503 /$ jecs20152.43.52

\title{
THE BIOPOLITICS OF VIOLENCE: INSTANCES OF ANTI-SEMITISM IN INTERWAR ROMANIA
}

\author{
Mihai Adrian Panu \\ Faculty of Political Science, Philosophy and Communication Science. \\ West University of Timişoara. \\ Blvd. V. Parvan, nr. 4, 300223 Timişoara, Romania \\ mihai.panu@e-uvt.ro
}

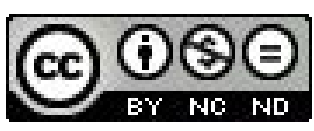

\begin{abstract}
The primacy of totalitarian ideologies in interwar Europe represents even nowadays a major historiographical challenge due to its multicausal character and various forms of appearance. This paper attempts to analyze the anti-Semitic phenomenon in interwar Romania primarily by taking into account its determinant factors. We assume that the emergence of radical ideologies in Central and Eastern Europe can optimally be understood if both regional and systemic causes are properly highlighted. The regional causes include local societal predispositions, ethno-cultural cleavages and specific political movements. On the other hand the systemic causes imply predominantly geopolitical factors and the repartition of power in the international system. Moreover we assume that the emergence and manifestations of extremism can be considered a direct result of political disputes between ethno-cultural groups which were systematically exposed to ideological and propaganda pressure.
\end{abstract}

Keywords: Anti-Semitism, Ethnicity, Biopolitics, Eugenics, Eastern Europe

\section{INTRODUCTION}

In the first half of the $20^{\text {th }}$ century Europe experienced major systemic transformations which profoundly shaped its socio-political profile. Most of those unprecedented changes were triggered by the primacy of radical ideologies especially after World War I. Between 1914 and 1918 the old European institutional framework collapsed as a result of various irreconcilable geopolitical positions and badly conducted diplomacy at the level of international affaires. The end of war brought the dawn of a new era dominated by (mostly) ethnically constructed nation-states. Those states, perceived as main actors on the stage of international relations, developed on the ruins of former empires, inheriting therefore most of their structural problems. From a historical point of view that structural cleavages were somehow inevitable at that time, mainly because the institutional design of Europe became obsolete and could not reflect any more social preferences and expectation. On the other hand, the tendency towards an establishment of nations-states (defined both ethnically and culturally) was already a strong social 
movement based on the widely spread ideas of nationalism. The new European order after World War I demonstrated the need of self-determination among states and the inevitability of an ethnically based nationhood.

However the new geopolitical design of Europe after 1918 prematurely revealed itself as problematic. Instead of accomplishing the much needed project of reconciliation, the European political stakeholders encountered new challenges and soon demonstrated their inability to avoid social, political and economic problems. There were several sources of imbalances for the European order established at Versailles. Most of them are related both to regional occurrences and systemic factors. Such a complex causal chain determined the emergence of phenomena which were difficult to predict and almost impossible to avoid. Among them, the rising anti-Semitism (with all its side-effects) represents a major scientific stake for the European historiography.

\section{THE RACIAL DIMENSION OF ANTI-SEMITISM}

The conceptual framework of anti-Semitism is significantly based on racial assumptions and theoretical constructions. Systematic attempts to scientifically deal with the problematic nature of race were undertaken as early as 1727 when the earl of Boulainvilliers tried to demonstrate that the aristocratic class of France has a superior ancestry (Proctor, 1998, p. 10). In the course of time racism became intimately connected with other various theories such as the geopolitical ones (Maull, 1939, p. 50). Especially in the first half of the $20^{\text {th }}$ century, racial theses - and other racially based (pseudo)-sciences - such as eugenics or biopolitics, gained a significant relevancy in various epistemic or political communities. The attempts to scientifically reinforce racism, were not necessarily genuine scholarly preoccupations but rather ideological campaigns designed to ensure a certain degree of legitimacy for extremist political movements such as NationalSocialism. The use of (pseudo)-science for legitimizing ideological discursive constructions became a strategic indoctrination method for both ideological twins which ravished Europe in the 20 $0^{\text {th }}$ century: National-Socialism and Communism.

Racism became theoretically structured in the $19^{\text {th }}$ century mainly because some scholars distinctively approached this subject. In his work "Essay on the Inequality of the Human Races" (1853-1855) Arthur Comte de Gobineau argued that race was the most important vector in world history. The idea of race perceived as a distinct evolutionary factor became quite appealing as soon as the organic imaginary related to state and nation gained a certain public relevancy. The importance of science in the process of shaping social perceptions or ideological discourses in the late $19^{\text {th }}$ century and especially in the first part of the $20^{\text {th }}$ century can not be underestimated. Racially based assumptions were gradually internalized by the public sphere simply because their simplistic argumentative construction fed various (moreor less) latent social preconceptions. For various political stakeholders "science became an important part of ideological argumentation and a means of social control" (Proctor, 1998, p. 13). Furthermore racially based science tried to 
influence the perception of otherness by creating desirable and undesirable racial categories according to their potential to internalize social rules and behavioral patterns. In this respect we can mention the work of Cesare Lombroso, "L'uomo delinquente" (1876), a systematic attempt "to identify criminal predispositions according to head forms and body markings" (Proctor, 1998, p. 13). In Europe there were some notable scholars who dedicated their work to the so-called race research. Among them Julius Lehmann, Alfred Ploetz or Eugen Fischer were leading figures (Proctor, 1998, p. 26).

In Eastern Europe the biologization of social representations was an insidious by-product of race-oriented science. After World War I the newly established nation-states tried to ensure their institutional and symbolic legitimacy by promoting a distinctive sense of political centralism which was not always well internalized by various minority groups. This was also the case in Greater Romania. The challenge of national legitimization in plural societies was simply too difficult for the Romanian political elite of that time. Instead of achieving social cohesion in the new nation-state, the symbolic appearance of political centralism and the struggle of constructing solidarity among people with different ethnocultural heritage and political loyalties, ultimately led to a dysfunctional societal system. In interwar Romania the representation of nationhood became more and more exclusive after the Great Union. In the process of constructing the national identity the old alterophobic preconceptions became manifest. Their impact at the level of public sphere was also facilitated (among other factors such as geopolitical predispositions or the radicalization of ideologies) by the complicity of (broadly speaking) racial science. The way science influenced nationalism and the construction of political identities in Eastern Europe after World War I, can not be optimally explained without taking into consideration the potential of political institutions and especially ideologies to instrumentalize convenient scientific discourses. Radical ideologies (such as Communism) usually claimed their scientific character. Their pretended scientificity became an efficient method in the process of mass indoctrination. The political stakeholders, especially in autocratic regimes, soon recognized the fact that, if enforced by (pseudo)science, their discourses and political arguments would have an increased chance to find public support and therefore to mobilize the masses.

There was not only pure racial science which functioned as a determinant factor for xenophobia or integral nationalism in Eastern Europe. Other (pretended) scientific branches such as biopolitics or eugenics also played a decisive role. Biopolitics, for example, was already in the $18^{\text {th }}$ century an important instrument of governmental practice, designed to rationally deal with distinct societal problems such as hygiene, natality or even racial issues (Foucault, 2007, p. 291). Foucault's conceptualization of biopolitics helps us understand the complex nature of governmental power and its impact at social level. The Foucauldian perspective focuses primarily on "the power to administer and produce life" (Campbell, Sitze, 2013 , p. 237) perceived as the ability of political systems to manage and control important societal processes (as mentioned above). Such a theoretical perspective is best suited for investigating the particular historical context approached in this 
paper. However the concept of biopolitics is far more complex. In order to properly understand its manifold meanings, we necessarily have to take into consideration the dual nature of this notion. Biopolitics is intimately linked to the concept of biopower: "By the first is meant a politics in the name of life and by the second a life subjected to the command of politics" (Campbell, Sitze, 2013, p. 352).

The interpretation patterns of the term "biopolitics" reveal three main branches. The first one is based on the works of Francois Ewald and Roberto Esposito who "analyze biopolitics from the standpoint of the normative management of population" (Campbell, Sitze, 2013, p. 238). The second major branch is based on the assumptions of Giorgio Agamben who investigates the emergence and development of biopolitics in the context of rising totalitarian regimes (Campbell, Sitze, 2013, p. 238). In the case of national-socialism, for example, the ideological stakeholders considered that the entire nation was an "organic capital of the state" (Alexander, Numbers, 2010, p. 202). Finally, the third interpretational pattern "(...) includes authors who understand life with reference to naturalistic and/ or transcendental invariables of existence. From this perspective there is a certain autonomy conceded to biopolitical subjectivity, for example, in the invariable logical-linguistic structures proposed by Noam Chomsky or the ontological duration of preindividual and interindividual linguistic and productive relations in authors such as Gilbert Simondon, Bernard Stiegler and Peter Sloterdijk" (Campbell, Sitze, 2013, p. 239).

As previously highlighted, in the $18^{\text {th }}$ century biopolitical-related measures were already in existence. However the term "biopolitics" gained its scientific relevancy in the context of rising geopolitical preoccupations in the first decades of the $20^{\text {th }}$ century. Rudolf Kjellen (who is considered one of the most important pioneers of geopolitics) was the first to employ the notion of biopolitics (Esposito, 2008, p. 16). In this particular case the idea of biopolitics illustrates the natural tendency of states to follow the logic of the so-called organic expansiveness and decline. Kjellen's assumptions served as a conceptual framework for consolidating racially-based theories such as the "Lebensraum" (vital space). The latter was promoted (among others) by German theorists of geopolitics such as Karl Haushofer or Friedrich Ratzel (Esposito, 2008, p. 16) and gradually became part of the N.S.-ideology.

The rise and consolidation of extreme-right ideologies had therefore multiple causes. It was neither solely a social predisposition nor an isolated political pathology. The roots of ideological extremism were divers and in most cases interdependent. In our particular case the (pretended) scientific movements, such as biopolitics, geopolitics or eugenics, decisively influenced the emergence and dynamics of political extremism in Eastern Europe contributing therefore to the so-called primacy of ideology. The gradual instrumentalization of various scientific branches, especially in interwar Europe, revealed the complicity that can be established between political stakeholders and other societal actors such as intellectuals. If reinforced by scientific discourses, political extremism usually becomes self-perpetuating, meaning that, once started the process of systemic radicalization of societies is hardly reversible. In this respect, it is essential to discuss the problem concerning the autonomy of science from political power. 
In totalitarian and even autocratic regimes such a precondition is difficult to be fulfilled. The primacy of ideology leads to an increased societal control and, as previously highlighted, to a gradual instrumentalization of relevant domains (science, culture, religion etc.). The key factor for understanding these complex dynamics involving organized political power and (non-political) societal spheres is the concept of ideology itself. Totalitarian ideologies peremptorily claim the monopoly over trueness in all its discoursive forms. Therefore, such an inherent pretension directly leads to the need to subdue and control all aspects of public life including epistemic discourse. The infallibility of radical political power overwhelmingly depends on its potential to control the mechanisms of knowledge. This fact explains many characteristics of totalitarianisms such as indoctrination, propaganda, censorship and, as previously explained, the need to instrumentalize the orientation of science. However, despite massive propaganda pressure and the claim to control everything, there was always a natural tendency to repudiate the existence of autocratic political structures. In this respect we can assume that even in times of harshest totalitarian oppression, some (few) ideologically uncontaminated epistemic communities sporadically continued their normal activities. In interwar Europe the potential of extremist discourses to infiltrate various non-political domains was a clear indicator of tremendous propagandistic energy. In many countries the public sphere lost the ability to democratically regenerate itself and to contain undesirable phenomena at societal level. Consequently the European society gradually became the playground for the most vicious totalitarian twins of the $20^{\text {th }}$ century.

\section{INTEGRAL NATIONALISM AND THE CONSTRUCTION OF THE ORGANIC STATE: THE CASE OF ROMANIA}

The historical existence of political entities was always influenced by their potential to assume and exercise legitimate power in a (more ore less) symbolically defined geographic space. Both states and nations have a dual existence. On the one hand, they are externally constructed, meaning that the international environments (and especially the geopolitical neighbourhood) define state and nations by employing their own criteria. In this case the identity formation in the international system primarily depends on the mechanism of perceiving the otherness at macro level. All actors of international relation have their own geopolitical reasons to define the political and cultural identity of other actors (including states and nations) according to their own realistically constructed interests. One of the most important requirements for states to act at the level of foreign affaires is to be officially recognized by other states i.e. actors of international system. Therefore the identity formation of states and nations also depends on external factors. On the other hand, states and nations (defined as political and cultural entities) can not emerge without the necessary amount of social acceptance. The political loyalization of people thus becomes an important precondition for the existence of states. Given the circumstances that, both states 
and nations are long-term collective projects, we have to admit that their historical evolution needs our proper attention.

The national identity presupposes the ability of states to invent and reinvent themselves according to the impulses originating both at internal and external level. As previously underlined, their existence has a dual character. In this respect it is relevant to investigate the possible sources of conflict which can destabilize political and social entities in their long term existence. Firstly, there are sometimes situations in which the external and internal constructed identities don't overlap. Nations sometimes tend to imagine their own political existence as geographically over-dimensioned. Consequently there is a constant geopolitical pressure in the international system. Secondly, most modern nation-states are not homogenous ethno-cultural constructions. Their plural social profile sometimes reveals structural cleavages. Different ethno-cultural groups try to influence the mechanisms of national identity formation by opposing their preferences to the expectations of other social categories (Jădăneant, 2015, p. 43). For example, the relationship between majority and minorities reveals such frictions. The national identity and all its defining elements are therefore constantly changing as a result of different interactions between discoursive constructions and social representations concerning the everlasting notions of identity and alterity: "Ethnicity, race, and nationhood are fundamentally ways of perceiving, interpreting and representing the social world" (Brubaker, 2004, p. 17). In Romania, as well as in other parts of Central and Eastern Europe, the heterogeneous social profile and the asymmetric ethno-cultural interactionism between groups, led to a constant struggle to impose a dominant discourse about the national heritage, development, identity etc. Given the fact that the Romanian history was (in most cases) scientifically constructed by employing concepts such as Romanianhood, ethnic groups, primordialism or even orthodoxy, the representations of nation and nationalism tended to be rather exclusive than integrative. After the proclamation of Greater Romania (1918), the political elites faced the difficult challenge of ensuring social cohesion among social groups with different ethno-cultural background. The attempts to gain the loyalty of all citizens by invoking the benefits of national unity and state centralism were less successful. The new Romanian state wasn't able to optimally manage the problems related to its own legitimacy. At an international level there were certain issues concerning the effects of the Versailles treaty and the possible revisionist attitudes in the geopolitical vicinity (especially Soviet Union and Hungary). Likewise, the internal processes in Greater Romania revealed the existence of ethnicity related problems, concerning primarily the intercultural dialog and minority rights. The existence of state centralism presupposed an increased interaction between politics and society. In such situations, the concept of ethnicity, understood primarily as "politicized social action" (Malesevic, 2006, p. 26), becomes an important feature of the public sphere. If used as a historiographic analytical tool, the concept of ethnicity has the potential to disclose the mechanisms of political mobilization and the predisposition of masses to follow extremist ideological movements: "Individuals and groups are still politically mobilised to fight for, to die or to kill for the preservation and defence of their 'identities' just as they were for the protection of racial hygiene or class unity" (Malesevic, 2006, p. 35). 
The emergence of integral nationalism and other ideological pathologies is less probable if the public discourse doesn't reveal alterophobic attitudes. Usually such undesirable behavioural patterns are strongly connected to an entire symbolic construction of nationhood based primarily on traditions. When facing the challenges of modernity, the dominant ethnic legacy (including latent preconceptions towards otherness), becomes ideologically entangled and therefore part of various propagandistic campaigns. Such assumptions were already theorized by various authors, such as Anthony Smith, who approached the complex domain of ethnic groups and their symbolic legacies: "Ethno-symbolism aims to uncover the symbolic legacy of ethnic identities for particular nations and to show how modern nationalisms and nations rediscover and reinterpret the symbols, myths, memories, values and traditions of their ethno-histories, as they face the problems of modernity" (Smith, 1998, p. 224). The relevancy of ethnosymbolist approaches in the field of historiography shouldn't be underestimated. This particular perspective offers a new way of interpreting the emergence of nationhood in Central and Eastern Europe. It emphasizes the importance of ethnically based cultural legacies which are considered more suitable for analyzing the mechanisms of national identity constructions. This approach is not necessarily a critique of the traditional causal relation between nationalisms and nations but rather an amendatory statement: "For ethno-symbolists, the role of nationalists in the creation of nations, although equally significant, is more modest and circumscribed. Their task is to rediscover, select and reinterpret the past or pasts of a given community, to reshape its conception of its present state and so help to regenerate the community. In this perspective, nationalism becomes a form of 'political archaeology' and nationalists political archaeologists seeking to place the community in its appropriate temporal and spatial contexts. Just as the archaeologist seeks to relate the excavated material culture to its historic time, so the nationalist aims to place his or her nation within its own time-frame by relating it to a rediscovered past or pasts" (Smith, 2009, p. 65). The main idea behind such statements is that the existence of modern nations depended not only on the manifest expression of a widely internalized nationalism but also on the subjective (Smith, 2009, p. 80) manifestations related to, more or less, dormant primordial energies and thought patterns.

The emergence of integral nationalism in interwar Romania found favourable societal and cultural conditions (such as the ones previously described). Compared to the legitimate form of nationalism (Risorgimento nationalism), which is identifiable in the context of rising nationalist struggles in $19^{\text {th }}$ century, not only in the Romanian space but also in many parts of Europe, the integral nationalism revealed a clear ethno-centred character. Among its main characteristics we can mention: racism, ethnic exclusiveness, xenophobia, a certain degree of militarism, anti-Semitic discourse and, of course, the organic representation of state and nationhood.

Given the fact that the Romanian interwar political extremism had both internal and external causes (as highlighted in a previous section) and our main objective is to analyze the scientific background of extremist discourses in the context of 
rising autocratic regimes, it is scientifically relevant to supplementarily investigate the scientific factors which contributed to the development of integral nationalism and therefore to the emergence of an organic representations of nationhood. In this respect we shall insist upon finding the (hidden) roots of political extremism by taking into consideration its unconventional auspicious elements. As we mentioned in the first part of this paper, there were some distinct local and systemic causes which facilitated the emergence of ethnicity based political extremism. Beside the (already) described relevancy of geopolitics and biopolitics, there certainly was a well established eugenic dimension of the Romanian interwar integral nationalism. The reason eugenics became ideologically instrumentalized resides primarily in its potential to facilitate racial/ethnic based interpretation of the social world: "The term 'eugenics' (from Greek: well-born) was introduced by Francis Galton in the 1880s, whose primary interest was selective breeding. Eugenics is based on the simple yet dangerous idea that those individuals with a positive genetic inheritance should be encouraged to breed while those with a negative hereditary profile should be discouraged from doing so, either through forced sterilization or judicial murder. This idea was popular among scientific positivists who believed that biology could resolve intractable social problems by applying rational principles of selection: if the weak, criminal or insane members of society could be eliminated through preventative measures or extermination, then the genetic inheritance of the population as a whole could be improved and the social costs of poverty, criminality and disease drastically reduced. In a utilitarian sense, the welfare of the greatest number would be increased by sacrificing undesirable stock, as a burden to the healthy majority" (Woodley, 2010, p. 197).

Eugenics gained a significant relevancy in the first part of the $20^{\text {th }}$ century as radical ideological movements tried to justify their propaganda campaigns by invoking the need to manage and efficiently solve social problems. In this respect political stakeholders underlined the importance of racial hygiene which was perceived and promoted as an important measure for ensuring the strength, vitality and cohesion of a nation. Eugenics rapidly became a constant feature of xenophobic political discourse not only in Romania but also in other European countries: "Eugenicist and natalist themes recur repeatedly in fascist racial science and race laws, not just in Nazi Germany but also in Italy, Croatia, Romania and Hungary, reflecting an inter-European concern with racial expansion and racial hygiene" (Woodley, 2010, p. 200).

The particular case of Romania reveals an obvious complicity between eugenics and ideology. Many important Romanian eugenists approached the problem of ethnicity (Turda, Weindling, 2007, p. 13) in an ideologically conformist manner, contributing therefore to the public legitimization of extremist discourses. The political commitment of the Romanian eugenic school represents an important symptom of that what we may call "the primacy of ideology in the public sphere". This unprecedented ideological infestation of various non-political domains (such as science) was possible mainly because the indoctrination potential of extremism was severely underestimated. The conceptual framework issued by authors such as Eric Voegelin, helps us understand that kind of indoctrination potential and 
the very intimate relation between extremist discourses and societal expectations. In this respect the totalitarian ideologies can be understood as veritable secular religions (Voegelin, 2010, p. 140) which are meant to ensure the human redemption not in the extra-mundane sphere (as traditional religions promise) but rather mundanely, during people's real life. The power of totalitarianism to indoctrinate masses resides predominantly in the ability of charismatic extremist leaders to convincingly present their redemptive programme.

\section{CONCLUSIONS}

The roots of anti-Semitism are deeply anchored not only in the political culture of Eastern Europe but also in the collective perception of otherness especially if the latter became ideologically infested. The paradox of plural societies in times of crisis consists primarily in their inability to avoid radicalization and to keep intact the social cohesion. As previously mentioned the emergence of totalitarian ideologies in the $20^{\text {th }}$ century represents a multifaceted phenomenon and can optimally be understood if the various predispositions are taken into consideration. Regional elements as well as systemic factors decisively influenced the manner totalitarianism became socially internalized and therefore it's potential to develop. The main objective of this paper was to investigate particular instances of anti-Semitism and to highlight its various, less obvious causes such as biopolitics, eugenics or the geopolitical determinism. In the case of Romania there was not necessarily a dominant factor which rapidly facilitated the social exposure to political radicalism but rather a group of concurring elements randomly favourable to it. Biopolitics and eugenics were ideologically instrumentalized in order to serve particular political goals. Developed in the first phase as distinct (pseudo)scientific branches they lost their epistemic autonomy and became ideologically entangled. Likewise the racial infusion of everyday life discourse represents a corollary of ideologized science. The existence of large societal cleavages in interwar Romania (and implicitly in Eastern Europe) also indicates an increased ideological pressure. The fact that scientific branches such as eugenics or biopolitics became a legitimizing factor for political extremism is not necessarily incriminating for the science itself. It rather demonstrates that, compared to politics, science has fewer defence mechanisms and can easily be subdued. On the other hand, geopolitics offers us a convenient systemic perspective about the frictions which can occur on the international stage especially in times of crisis. As a consequence of World War, the entire geopolitical profile of Europe was reconfigured. On the ruins of multi-ethnic empires, nation-states emerged. This represented a major switch not only at the level of politics and institutional design but also at the level of group's identities, perceptions and expectations (KührerWielach, 2014, p. 15). As previously emphasized, the attempts made by various political stakeholders and governing parties to gain the loyalty of all citizens, by simultaneously promoting the idea of state centralism, eventually failed. Consequently, the idea of ethnicity gained a significant importance and decisively 
influenced the public discourse. Instead of creating social cohesion and the conditions for sustainable state development, many Romanian political elites of that time, couldn't avoid the totalitarian ideology traps. The various manifestations of anti-Semitism in interwar Romania can be perceived as a result of a systematic long-time geopolitical deterioration which reached its climax in the aftermath of World War I. Nevertheless, xenophobic attitudes and extremist tendencies also had a non-political character simply because they were socially constructed at a discoursive level in everyday life. The public acceptance of unacceptable social practice and discourses represents, in many cases, perhaps the key ingredient for understanding the internal preconditions of extremism in plural societies and eventually the complex political metabolism of interwar Europe.

\section{ACKNOWLEDGMENT:}

This work was cofinaced from the European Social Fund through Sectoral Operational Programme Human Resources Development 2007-2013; project number POSDRU/159/1.5/S/140863, Competitive Researchers in Europe in the Field of Humanities and Socio-Economic Sciences. A Multi-regional Research Network.

\section{REFERENCES}

Alexander D., Numbers R.(2010). Biology and ideology from Descartes to Dawkins, Chicago: The University of Chicago Press.

Brubaker R. (2004). Ethnicity without groups, Cambridge: Harvard University Press.

Campbell T., Sitze A.(2013). Biopolitics. A reader, London: Duke University Press.

Esposito R. (2008). Bios: Biopolitics and Philosophy. Minneapolis: University of Minnesota Press.

Foucault M. (2007). Naşterea biopoliticii. Cluj: Editura Idea Design\&Print.

Jădăneanț A.(2015). The Collapse of Constitutional Legalism: Racial Laws and the Ethno-cultural Construction of National Identity in Romania during World War II. Procedia - Social and Behavioral Sciences, Volume 183. 40-46.

Kührer-Wielach F. (2014). Siebenbürgen ohne Siebenbürger? Zentralstaatliche Integration und politischer Regionalismus nach dem Ersten Weltkrieg. Band 153 der Reihe "Südosteuropäische Arbeiten". Berlin: de Gruyter.

Malesevic S. (2006). Identity as Ideology. Understanding Ethnicity and Nationalism. New York: Palgrave Macmillan.

Maull O.(1939). Das Wesen der Geopolitik. Leipzig: Teubner.

Proctor R. (1998). Racial Hygiene: Medicine under the Nazis. Harvard University Press.

Smith A. (1998). Nationalism and modernism: a critical survey of recent theories of nations and nationalism. London: Routledge.

Smith A. (2009). Ethno-symbolism and Nationalism. A cultural approach. London: Routledge.

Turda M., Weindling P. (2007). "Blood and Homeland": Eugenics and Racial Nationalism in Central and Southeast Europe, 1900-1940. Budapest: Central European University Press.

Voegelin E. (2010). Religiile politice. Bucuresti: Humanitas.

Woodley D. (2010). Fascism and Political Theory. Critical perspectives on fascist ideology. London: Routledge. 